\title{
Metrical patterns and layers of sense: some remarks on metre, rhythm and meaning*
}

\author{
João Batista Toledo Prado \\ State University of São Paulo, Araraquara
}

\section{Introduction}

Ideally, all metric phenomena should be observed as empirically as possible on the phonetic-phonological dimension of a language. Empirical observation has however considerably restricted limits when it comes to classical languages, due to the present manifest reductions created by their historical fate, which puts them among those idioms not any longer spoken today.

Only legitimate speakers of the Latin language, that is, those who have had it as their mother tongue, were totally able to empirically experience features such as cadence, harmony, rhythm of speech as well as other traits crafted by versification techniques, especially when one takes into account the fact that, from a certain time on, almost all verse compositions in Rome were meant to be read aloud and for public performances ${ }^{1}$. The

I wish to thank FAPESP (São Paulo Research Foundation, Brazil) for the granting of a scholarship that allowed me to develop a post-doctoral research in France of which the final form of this text is one of the many results.

Dupont $(1985,402)$. 
standards set by classical metrics were also based on the phonic qualities of the articulate sounds, and metrics treatises, written by ancient scholars as well as those produced by later critics, have always involved sound matter on the basis of their settings for the metrics phenomenon in poetry.

Classical Metrics manuals have always sought to catalog regularities seen in classical poetry and formulate the standards of its occurrence in verses, by proceeding to investigate their harmony measures, i.e., poetic meters, and establishing the laws that rule their use as well as the effects produced by them, but always based on the sound phenomenon of ancient languages like Greek and Latin, which could not deliver to posterity any positive evidence of how their phonemes were articulated. Metrics studies as a form of research and better understanding of poetry demand some sense, however, only in the grounds of prosody. This subcategory of Poetics involves much of the materiality of language, i.e., the plane of articulate sounds. This seems to be the biggest problem faced today by Metrics studies, either as a didactic and pedagogical component in the study of classical poetry, or as a valid instrument to investigate the poetic nature of classic literature.

The fact that it is no longer possible to empirically observe phonetic data of a given language has a direct impact on the project of studying the expressiveness of a poetic form. However, this would be desirable, because the understanding of the expressiveness domains may help to achieve layers of meaning that lie beyond and/or above the mere sense of phrasal sentences, by strengthening them and apparently materializing them in the phonological level, by contrasting them and creating effects of all kinds in sense layers that expose themselves only when one takes into account this level of articulation in conjunction with that of the poetic phrase.

The procedure which overcomes those restrictions imposed by the historical fate of the Latin language (and of the Greek and other languages no longer spoken today) is processing and 
analyzing data of sounding not in their material aspect, but in the interplay created by poetic contrasts, and this is achieved by investigating the prosodic plane of poetry without taking the nature of sound in consideration, but its oppositive differences instead, which are located in the formal system of the Latin language. This procedure features a linguistic and at the same time literary approach to the field of poetry.

This form of poetry analysis will be illustrated through critical reading of technical procedures consigned by the classical Latin poetry studies. At the same time, we intend to propose mechanisms for initiating an analysis of the expression plane, by applying them to to the reading a passage from one of Tibullus' Elegies, composed in the Age of Augustus.

Notwithstanding the specificity of the analyzed corpus, the intended goal here is to show in which ways a poetics of the expressiveness can be an efficient tool to read poems composed in the Latin language, as well as to put in evidence the social character of any academic investigation, in this case because it involves a study of the Latin language as an overcoming of the merely scholar knowledge, made possible through a philosophy of language and a reflection that operates on the form instead of on the substance, either when it comes to the expression plane or when it comes to the linguistic contents. The notion of language philosophy implies here that substance is put aside, be it phonic, graphic or of meaning, for the benefit of what is perceived only psychologically in the relations between signifier and signified.

\section{Some Benchmarks}

Modern readings and approaches to Greek and Latin classical poetry are in general made from biases that include analysis of its thematic traits, its discursive-rhetorical articulations, consideration of the settings of its poetic images and critical views of the codes and sub-codes belonging to the genres 
that guide verse composition. Except for one or another more salient feature employed by the poet, phenomena on the textual surface of a poem, that is, in the dimension of the form of the expression plane, do not usually play a major role in most of the analyses; nevertheless they are responsible for engendering layers of meaning other than that of the content plane. In most cases, they thicken the meaning conveyed by the text, ultimately reaching the highest and fullest degree of iconicity, when the content plane and the expression plane fully converge, creating an impression of identity with the real world. Those are naturally privileged moments of poetic expression, where a text manages to produce a referential illusion in order to establish a "similarity of relationship" with manifestations of extra-linguistic reality ${ }^{2}$.

Full iconicity is not always attained, of course, but generally great poets employ resources of convergence between planes, so that they can conform them to construct a cohesive poetic speech in order to generate a permanent effect, in which a given poetic form predominates over time. Sometimes, however, the expression plane is organized in a form leading to the construction of alternative layers of sense, which are subtexts that expand and dialogue with the basic text.

On the other hand, the most common forms of analysis to read and interpret classic poems, through their thematic features, rhetorical-discursive formations, settings of poetic imagery and critics to codes and sub-codes of literary genres, are compliant with an epistemic philosophy according to which every speech act is an articulation between themes and figures - respectively the most abstract and the most concrete level - so that a given theme is manifested through the installation of figures in the text, which is already a classical idea in the Greimasian semiotic theory (even though the Greimasian semiotics is a theory still in progress). Those most common forms of analysis achieve the conception that it is through such resources that meaning is built.

2 cf. Greimas; Courtés (1983, 222-3), s.v. 'iconicity'. 
One can claim that analyses of this type are compatible a priori with the semiotic theory of A. J. Greimas. Since this theory is still in its fieri, only in more recent times it does begin to deal with the articulations of sense made on the expression plane as an important part for the production of poetic meaning, and it may have already achieved successful results.

In general terms, although the expression plane has not been privileged in methodologies of full poetic analysis, the starting point for the considerations that favor this component as a mechanism capable of studying the production of the poetic sense and poetic ability to express poetry, had already been formulated in a simple but appropriate question, such as: - What makes one statement a poetic message? Or, in an even more direct way: "What makes a verbal message a work of art?"

More specifically in the field of the classical studies, similar intuitions have been suggested in the course of time, so that the famous Jakobson's question could be linked to Whiton's booklet Introduction to prosody of Latin, according to which many errors could be avoided if the verses of Latin poets were taken as simply poetry:

I think that many make a false beginning in their Vergil, or Ovid, by not beginning it as poetry. While the first month's reading-lessons are progressing, the pupil is learning prosody from the grammar. Until this is done, an initiation into the mysteries of scanning and proving is deferred. One or two books of Vergil - often more - are accordingly read with as much indifference to metre and rhythm as if they were so many books of Caesar. The only difference that this method enables a pupil to discern between prose and poetry is, that poetry allows what seems to him a much more blind and confused arrangement of words. A poetical author ought to be treated as such from the outset, and no false dealing with the subject should be allowed. To facilitate a true beginning by abridging and simplifying the

\footnotetext{
Jakobson (1960, 350).
} 
introductory lessons is the object of this primer, which, I recommend, should be mastered before commencing to read "Arma virumque" or "Ante mare et tellus".

Controversial and bold as it may seem, it is certain that if on the one hand Whiton's recommendation seems to suggest a methodological renewal, its practice, on the other hand, focuses on the still somewhat mechanical observation of the laws of meter and verse.

Anyway, later on others will continue and give greater consequences to the use of metrics data in the reading of Latin poems. Perhaps an eloquent example could be the first considerations of A. Cartault's work (1911), now classic, on the elegiac couplet. Cartault's book begins the first chapter with a kind of warning to the reader, based on the following consideration:

The proportion of dactyls and spondees in verse is very important; that is what gives its color and rules its movement; the prevalence of dactyl reveals the dactylic rhythm, and the prevalence of the spondee obscures it; the dactyl is light, bright and cheerful; the spondee is heavy, serious and stable; the frequency of one or the other can provide the poet with a means of expression ${ }^{5}$ (emphasis added here).

However, although complete and rich in details, Cartault's study focused on extensive statistical surveys, numerous variation catalogs, and metrics inventories, all based on what can be found in the poems contained in the Corpus Tibullianum, but still

\footnotetext{
Whiton (1879, III).
}

5 Cartault $(1911,5)$ : "La proportion des dactyles et des spondées dans les vers a une grande importance; elle lui donne sa couleur et règle le mouvement; la prédominance du dactyle accuse le rythme dactylique, celle du spondée l'obscurcit; le dactyle vif et alerte est léger, le spondée stable et grave est lourd; la fréquence de l'un ou de l'autre peut fournir au poète un moyen d'expression". Unless otherwise noted, translations from foreign languages into English in this text were prepared by its author. 
without integrating more effectively the occurrence of metric features on the reading of a poem as a poetic device. However, Cartault's work draws the reader's attention to the possibilities of observing such data to achieve a better understanding of the poetic expressiveness, which, under its ultimate consequences, could contribute to a Poetics whose privileged object should be the expression plane or the expressive effects of the poetic text, that is, its expressiveness.

It is always worth remembering that etymologically expressiveness derives from exprimo (ex + premo), whose usual meanings include, for example, to squeeze or press (to extract a liquid, etc.), wring out; to press (clothes); to extract by pressure, squeeze out; to eject by pressure; to squeeze outwards; but also to model, reproduce, translate, and even pronounce, articulate, utter and even to express. At least those are the most frequent meanings listed by trustworthy lexicographers ${ }^{6}$, who add also, in the form of the adjective expressus, $-a$, - um, the meaning of high, protruding, prominent, therefore, it can be inferred that its meaning could be described by something that, when pressed, is brought out and remains protruding, prominent, hence, something that appears, and draws attention.

Some benefit can be drawn from these etymological considerations because the concept of a Poetics of the Expressiveness intends to evoke a whole set of poetical devices. Those devices first occur in the expression plane of a poem and derive from the expressive value of the signs. This feature has already been pointed out by critical thinkers like Charles Rosset ${ }^{7}$, and that sums up the concept of expressiveness. Meaning traits like protrusion, elevation and prominence may consider as expressive all poetic utterance (and it is worth remembering that, although Latin poems are concerned here, this naturally does not happen exclusively in texts written in verse). Constituting

\footnotetext{
6 Cf., e.g., Glare (1968, 652-3) s.v. "exprimo”.

7 Rosset (1970, passim).
} 
instances of particular density of that formal confluence between the two planes of language - a moment of great formal convergence - on which any text is structured, these expressive utterances stand out from others because of their high isomorphic density, which generally leads to the impression that a given form of content can only be expressed by a given and particular form of expression. This is perhaps what leads to the desire to know poems by heart, to quote them, to recite them and to repeat them, without producing, however, any exhaustion or satiety.

Regarding the isomorphism between expression and content, and the expressive character that are in all the poems, it must be said, at first, that this trait may permeate the entire poem (and most likely that's the rule!). Nevertheless, there are passages in which such feature becomes more evident than in others, because it is ultimately a matter of degree and intensity by which a given passage demonstrates it. On the other hand, the isomorphism and, moreover, all other concepts mentioned so far, have been developed by prestigious and influential authors, even though they don't state their findings with this term, more familiar, perhaps, to the semiotics of our times.

Considering Jakobson's previous question ("What makes a verbal message a work of art?" $\left.{ }^{8}\right)$, he tried to answer it by suggesting a confrontation between the place traditionally occupied by poetry studies, i.e., by the Poetics, and the science of the language phenomena, the Linguistics, in order to determine under what perspective should be seen those linguistic utterances, produced according to artistic criteria:

Because the main subject of poetics is the differentia specifica of verbal art in relation to other arts and in relation to other kinds verbal behaviors, poetics is entitled to the leading place in literary studies.

Jakobson (1960, 350). 
Poetics deals with problems of verbal structure, just as the analysis of painting is concerned with pictorial structure. Since Linguistics is the global science of verbal structure, poetics may be regarded as an integral part of linguistics. ${ }^{9}$

Jakobson comes to the conclusion that the Poetics should be seen as a branch of Linguistics and it should be submitted, in general, to the same analyzing procedures of the structures that are adequate for each type of enunciation - which is in accordance with the idea that poetry is one of the aspects of language, as stated by Fónagy ${ }^{10}$. Jakobson's proposition is that this should be done through an analysis that takes into account the functions performed by language - a theory created and developed by Karl Bühler - among which there is the poetic function: "Language must be investigated in all the variety of its functions. Before discussing the poetic function we must define its place among the other functions" and "The verbal structure of a message depends primarily on the predominant function"11.

The use of versification tends to produce a dominant role for the poetic function - since only there can a regular and recurring use of phonological matrices produce the sense that a message carries, when configured that way. But the versification alone is not enough to produce poetry (as stated at least since Aristotle's Poetics ${ }^{12}$. To do that, there must be a confluence between the two planes of language, in a formation combining phonological featured elements with significant sentence traits. It is Jakobson who once more acknowledges this fact, stating that "Mnemonic lines [...], modern advertising jingles, and versified

\footnotetext{
Jakobson $(1960,350)$.

Cf. Fónagy $(1966,72)$.

11 Jakobson (1960, 353).

12 Cf. Arist. Poet. 1447b: "They are in the habit of calling any writer of a medical or scientific treatise in metre a poet, but in fact Homer and Empedocles have nothing in common except the metre, so that one should call Homer a poet and Empedocles a physicist rather than a poet" Hammond $(2001,13)$.
} 
medieval laws [...], or finally Sanskrit scientific treatises in verse [...], all these metrical texts make use of poetic function without, however, assigning to this function the coercing, determining role it carries in poetry"13.

\section{A reading and analysis example: Tibullus 1.10.1-10}

A reading of a poetic passage based on analysis of the articulations between the expression and the content planes now follows, taking into account the role of metrics and rhythm in verse and their tendency to "resonate" in accordance with the form of the content plane. The following five pairs of lines (or couplets or stanzas) of Tibullus' elegy 1.10.1-10 were reproduced below according to the text established by Max Ponchont ${ }^{14}$, with metric notations, as well as penthemimeris caesuras assigned by A. Cartault ${ }^{15}$ and supplemented as needed with other phonotactic elements by the author of this text (such as main and secondary caesuras, sandhis and synaloephas):

13 Jakobson $(1985,359)$.

14 Ponchont $(1989,75)$. Actually, the text edited by Max Ponchont was used here with only two minor changes: v. 4 tum (instead of $\boldsymbol{e t}$ ); though Cartault (1909, 192) and Ponchont $(1989,75)$ have chosen et, more modern researchers have chosen tum cf. Murgatroyd $(1980,44)$ or Juster $(2012,54)$ its variant tunc; Maltby (2002, 97); v. 9 somnumque (instead somnosque); again, somnos is supported by Cartault (ibid.) and Ponchont (ibid.), while Murgatroyd, Maltby and Juster use somnum. Though an older researcher, it is worth mentioning that Postgate has also preferred somnum in v. 9; and incidentally tum too in v. 4 Postgate $(1912,244)$.

15 Cartault (1911, passim). Cartault makes a thorough and detailed inventory of the caesuras as well as a statistical projection of all elisions and synaloephas found in the elegies of the Corpus Tibullianum, but he does not take into account the sandhis nor discusses the secondary caesuras, since they exist in a potential state. Even though potential - they exist in a latent state but can be activated and thus felt - they work as a hint of caesura and represent some psychological impact. After all, caesuras are not necessarily cuts nor breaks in the phonological sequence of a verse: they are moments of a certain emphasis that can be perceived by the adressee of the poetic speech, although in a surreptitious manner. 


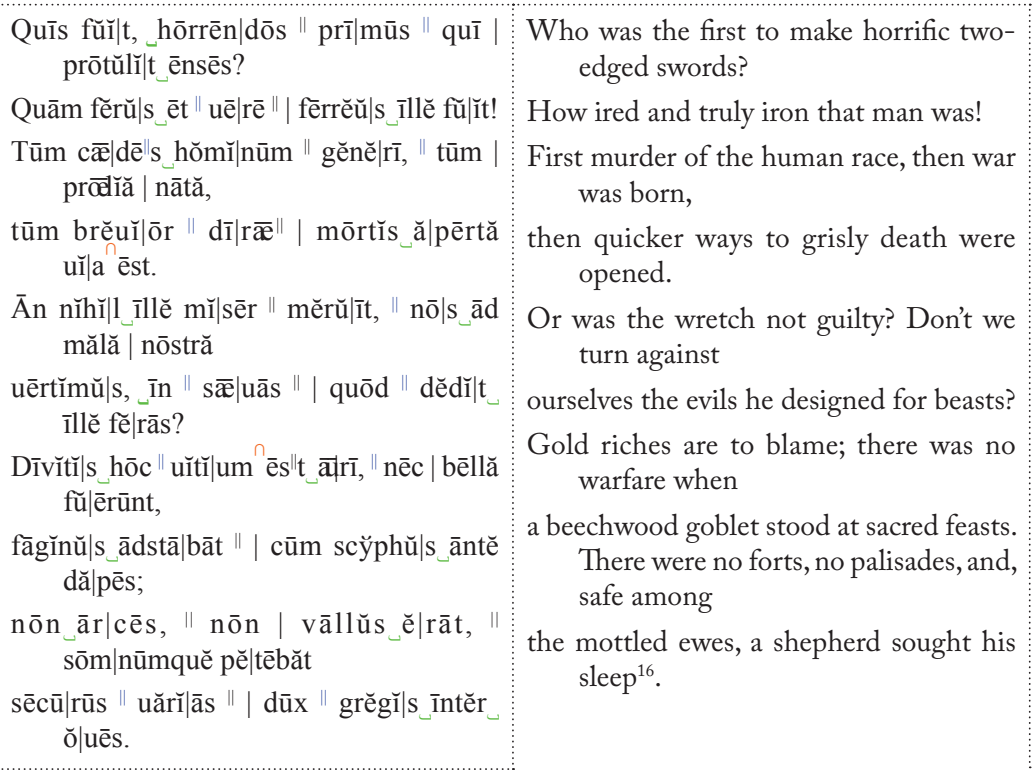

\begin{tabular}{|c|l|}
\hline Distich & \multicolumn{1}{c}{ Analyses/Commentaries } \\
\hline 1-2 & $\begin{array}{l}\text { Hex.: besides the remarkable reiteration of multiple and simple } \\
\text { vibrant phonemes (in horrendos, primus and protulit) that reinforces the } \\
\text { accumulation of dental and bilabial plosives (in fuit, horrendos, primus } \\
\text { and protulit), with which the poet seems to build, on the plane of the } \\
\text { form, the noise figure of a clang, like the clash of swords, it must be also } \\
\text { noted that the caesura of this verse is penthemimeris (between horrendos } \\
\text { and primus), with a suggestion of a secondary caesura hephthemimeris, } \\
\text { after the last syllable of primus. This feature highlights the term between } \\
\text { caesuras: primus; doing so at the exact center of the opening verse of } \\
\text { the elegy I, 10, the poetic speech underlines its elocutory key (after all, } \\
\text { primus is also the fourth word of a set of seven), namely, the presence } \\
\text { of a founding myth, i. e., of a character, be it a god, a demigod or a } \\
\text { human inspired by a } \text { numen, who has first conceived the idea of making } \\
\text { swords; the sense of disapproval of that act considered as criminal in } \\
\text { the speech of this verse, and communicated in the content plane, also } \\
\text { seems to find support in the form of the expression, through the sum of } \\
3 \text { cumulative spondees, occupying almost the entire verse, from the } 2^{\text {nd }} \\
\text { to } 4^{\text {th }} \text { feet, to which is also added the initial long syllable of the } 5^{\text {th }} \text { foot; } \\
\text { this construction still finds an echo in the } 6^{\text {th }} \text { final foot of this hexameter } \\
\text { one out of the only two spondees in the final position in this passage), }\end{array}$ \\
\hline
\end{tabular}

16 Transl. by a.n. Juster (2012, p.15) 


\begin{tabular}{|c|c|}
\hline & $\begin{array}{l}\text { which causes the phrase to suffer a delay, to be in a slower rhythm and } \\
\text { to have a solemn emphasis on the monstrosity of that act, considered } \\
\text { as a disaster for all mankind. } \\
\text { Pent.: uere ("really") is also highlighted in this pentameter, as it is situated } \\
\text { between the fixed caesura (between uere and ferreus) and a suggested } \\
\text { secondary caesura, a trithemimeris placed between et and uere, as if to } \\
\text { mark the unequivocal judgment about the fierce nature - inhuman } \\
\text { perhaps? - of the inventor of swords. Another feature is the reiteration } \\
\text { of the fricative phoneme "f", generally followed there by the vowel } \\
\text {-e-, which seems to echo the initial syllable fe-from ferus scattered all } \\
\text { over this verse, as if it was a rhetorical amplification of the very idea } \\
\text { of fierceness. }\end{array}$ \\
\hline $3-4$ & $\begin{array}{l}\text { Hex.: The main caesura is a penthemimeris one, located after bominum, } \\
\text { which divides the two hemistichs approximately in half and it is flanked } \\
\text { by two secondary caesuras: the first one a trithemimeris, between caedes } \\
\text { and hominum, the second one, a hephthemimeris, between generi and } \\
\text { tum. The result of this is the enhancement of the phrase bominum } \\
\text { generi ("for all mankind"), setting a tension that comes from a two-pole } \\
\text { opposition, formed by tum caedes ("then the slaughter") on one side, and } \\
\text { by tum proelia ("then the fighting") on the other side; both segments } \\
\text { flank and at the same time involve "the human race", that has to suffer } \\
\text { such damages due to the invention of weapons. The structure of this } \\
\text { verse is SDDS - i.e., it consists of two slow, wide pace and solemn } \\
\text { spondees, involving two fast and easy pace dactyls - and it also seems } \\
\text { to reinforce and create concrete contours supporting this same idea in } \\
\text { the materiality of the verse. } \\
\text { Pent.: in this verse, the fixed caesura (after dirae) also finds the } \\
\text { unexpected support of a trithemimeris secondary caesura, which isolates } \\
\text { both the word dirae ("fearful"), an attribute for mortis ("of death"), } \\
\text { and the initial phrase tum breuior ("then faster") which agrees with uia } \\
\text { ("route"). Such an idea is capital there because: a) the "route" of the } \\
\text { syntactic-semantic relationships between words is built by means of } \\
\text { a concrete and transverse movement which runs from breuior in the } \\
\text { beginning up to uia at the end of this verse; b) moreover, a synaloepha } \\
\text { between uia and the verb est is also ultimately building in prosody an } \\
\text { expediting effect that materializes in the expression plane the very idea } \\
\text { of a shortest route now opened to death, because of the invention of } \\
\text { weapons. }\end{array}$ \\
\hline
\end{tabular}


\begin{tabular}{l|l|} 
5-6 & $\begin{array}{l}\text { Hex.: only in the hexameter of the verse 5, the dactyls (the three first feet) } \\
\text { come to predominate, giving a more sprightly and smoother pace to the } \\
\text { sentence utterance, precisely when the poetic speech also softens a little } \\
\text { and asks if the now poor inventor of weapons was even to be blamed } \\
\text { for the misuse of his invention, which may have been only misused by } \\
\text { the modern era men (that is, the contemporary fellows to Tibullus), } \\
\text { who instead of using weapons to protect themselves against beasts, have } \\
\text { been using them to kill each other. The main caesura occurs there after } \\
\text { miser and is followed by an incidental hephthemimeris after meruit, a } \\
\text { procedure that isolates and highlights the verb meruit ("earned") and, by } \\
\text { doing so, also highlights and protrudes from the phrase two isometric } \\
\text { halves which are nevertheless opposite in sense: on the one hand, there } \\
\text { is an ille in the first hemistich, which creates a rhetoric tension to a nos } \\
\text { in the second one, and which means that "he", whoever the inventor of } \\
\text { weapons may have been, may not have had a malicious intent, nor is he } \\
\text { to be blamed, therefore. The contemporary countrymen of Tibullus - } \\
\text { according to the myth of the Ages of Man (quattuor aetates) } \text { (17 }^{17} \text {, one can } \\
\text { suppose they are all men of the Age of Iron - have distorted a worthy gift } \\
\text { by using it to shed the blood of their fellow men. It is also noteworthy } \\
\text { the enjambement which causes a reading movement there, featured by a } \\
\text { certain suspension of the logical progression, creating an expectation that } \\
\text { will be remedied only when the verb uertimus ("we return") is reached, } \\
\text { in the first foot of the pentameter. Needless to say, the enjambement is } \\
\text { not a very common resource in Tibullus' distichs; besides, at this point }\end{array}$
\end{tabular}

17 In his commentaries to Tibullus 2.3.35-6, Miller $(2002,153)$ states that "The theory of the four ages, gold, silver, bronze, and iron, is first found in Hesiod and becomes a favorite topos for Roman poets in the Augustan age"). The Ages of Man are four in the Ovidian version (Ov. Met 1.89-150), and it is important to note that the concept of a qualitative lowering in the ages of humanity arises from this myth, which features a metal degradation beginning with the Age of Gold (or simply Golden Age), successively followed by the Ages of Silver, Bronze and Iron. The allusion to the Age of Gold, a paradisiacal time for all mankind, fits well in the general framework of the elegiac poetry, since the idea of an innocent humanity, not yet corrupted by greed, befitted the general criticism to the venality in love relationships and to gold as a symbol of the corruption of customs, which predominates in the last and most criminal of all Ages, that of Iron. This myth first appeared in the poetry of Hesiod (cf. Hes. Op., 109-201), which also describes an Age of Heroes (cf. Hes. Op., 156-73) between the Ages of Bronze and Iron, thus forming the five Ages of Man. Although this myth is widespread in classical literature, Grimal (2005) presents a small inventory of the occurrences of the Golden Age myth in some of the Greek and Latin poets cf. Grimal (2005, 241), s.v. 'Idade de Ouro'. For further information on the genesis and especially on the structure of this myth in Hesiod, one should refer to Vernant's (1965) very instructive article. 
of the sentence, it makes concrete and almost "material" the concept expressed by the verb uerterre ("to return"), whose etymology, incidentally (or not), is exactly the same as the etymology of the word uersus ("verse").

Pent.: occurring after saeuas, the fixed caesura of the pentameter is balanced there by a secondary trithemimeris after in and also by an unusual secondary hexamimeris ${ }^{18}$ after quod; the result is an enhancement of the term saeuas ("wild"), an adjective that agrees with feras ("beasts"); the emphasis in this passage seems to affect the phrase in saeuas at the end of the first hemistich, and feras, at the end of the verse; that is, for allocating these words in prominent positions, it is emphasized the sense of the content plane, that is, the fact that weapons served primarily in saeuas feras ("against the wild beasts"), not against men themselves.

18 A real or potential, primary or secondary caesura occurs every time when two units of the lexicon cut a metric foot (cf.: "In assoluto, si ha cesura ogni volta che la parola 'taglia' (caedo) il metro". PERINI, 1982, p. 219) in two - this is of course a figurative cut - that is, it occurs by means of a sort of tension brought by the superposition and confluence of two different systems: that of a given language, which is taken as if it were plastic matter, and that of poetics which projects itself on a given language that becomes a constitutive part of it. Thus, even if it exists only in a potential condition, this pentameter shows the suggestion of a hexamimeres caesura; it is worth noting that the usual caesuras, both in hexametric and in pentametric lines, are penthemimeres. As for the hexameter, there is also the possibility of a balanced pair of caesuras: a trithemimeres and a hephthemimeres. Perhaps the hexamimeres caesura would go unnoticed and inactive there, had it not been for an also potential trithemimeres caesura that infiltrates itself between the preposition in and the adjective saeuas. The pentameter has always a fixed penthemimeres caesura, a fact that certainly mitigated other potential caesuras, relegating them to the status of mere psychic suggestions; when the suggestion occurs, however, it exists, persists and acts in order to highlight the segment in which the main caesura lies. Manuals of Classic Latin Metrics usually treat a phrase formed by preposition plus noun as just one word, separated only by a graphic convention - which is sometimes called metrical or phonetical words [cf. Nougaret $(1956,5)]$. The argument raised, for example, by Nougaret (ibid., § 10) is based on a passage by Quintilian (1.5.27). The French scholar, however, quotes only a portion of Quintilian's passage and he does not discuss the context in which the opinion conveyed by Quintilian is inserted. The full passage reads (the passage as quoted in Nougaret's Manual is underlined here as follows): Mibi videtur condicionem mutare, quod his locis verba coniungimus. Nam cum dico 'ircum litora', tanquam unum enuntio dissimulata distinctione, itaque tanquam in una voce una est acuta, quod idem accidit in illo 'Troiae qui primus ab oris' ("It seems to me that the circumstances are quite different here because in such phrases we use to join words. For when I say circum litora - near the shore - $\underline{I \text { utter it as in a }}$ 
7-8 $\quad$ Hex.: following the DDSS scheme, with the initial dactyls covering two-thirds of the first hemistich and whose meaning is somewhat neutral, the interplay (or reciprocal action) between dactyls and

single voice emission, concealing the distinction between the two words; this way, it contains just a single accent since I pronounce it as a single word. The same occurs in Troiae qui primus ab oris - 'the first one who, from the shores of Troy..." "). It is noteworthy that the question for Quintilian is the occurrence of a single accent in the phrase, and the verse 1 from the Aeneid provided by way of example is also a proof of that. Quintilian seems to draw attention to the fact that the quoted line reads Troiáequi and abóris, but it is significant that the first case is analogous to the enclitic conjunction -que, and that the second case is a matter of sandhi between $-b$ (from $a b$ ) and $o-$ (from oris), two phonotactic phenomena that explain the coalescence between those words. We might also infer that the "single accent" noted by Quintilian refers probably to the main and most prominent accent of the two words that form circumlitora. The quoted passage of Quintilian has great interest, especially for discussions on the demarcation function performed by accents and on the ways they were probably pronounced in Latin (especially in the post-classical Latin, at the time when Quintilian lived), but it does not relate either directly or exclusively with different units of the lexicon being perceived as a single and amalgamated entity. Quintilian witnesses, instead, the speaker awareness acting as to distinguish those two units, even if they were uttered in the same vocal emission; one should note the ablative absolute dissimulata distinctione, that is, the only and same emission testified by Quintilian masks at the phonological level something that the linguistic competence of the speaker always realizes: the fact that the phrase contains two items of the lexicon. This happens because prepositions are independent forms and they form syntagmas with any lexical entities that satisfy their grammatical constraint of triggering a case marking in a given noun. Thus, while listening to that pentameter of Tibullus, the listener-adressee certainly knew that there is no single entity equivalent to insaeuas in the Latin lexicon, therefore, his conscience and speaker competence were able to recognize the preposition and the adjective that form the phrase in saeuas... (feras). Such a conscience should be produced by the contrast between the independent status of a preposition like in (capable of forming phrases with any nouns of the linguistic repertoire of the Latin language, and of triggering case marks in them) and other similar forms like the prefix in, a dependent constituent which does not trigger case marks and whose grammatical forms are provided and included in the language repertoire (cf. inabruptus, "not broken"; inaccessus, "inaccessible"; inadustus, "non-combustible", etc.). This is an essential and unanswerable difference that raises awareness, yet intuitive, between prefixes and prepositions in Latin language, and a fact that always regulates the individuality of a ruler preposition and therefore this does not allow it to be confused with a ruled noun, even though the resulting syntagma was pronounced in the same vocal emission. As for the rest of this issue, in the phonological level of the linguistic 
spondees serves to reinforce the weight of spondees which give gravity to the idea conveyed there: the evil caused by the hunger for gold is the real cause of wars. Indeed, the penthemimeris caesura after est ("is") finds itself counterbalanced by a secondary trithemimeris after hoc ("this"), and a hephthemimeris after auri ("of gold"), which ultimately highlights the phrase uitium est auri ("the gold is to blame"), which is the key argument of the whole first part of the poem, and that also echoes the elegiac topos as well as a wide literary tradition of putting the blame for all warlike atrocities committed by men on their insatiable hunger for gold, that is, on their greed ${ }^{19}$. and accumulation (of goods) are reinforced by two phonotactic resources: the sandhi, which lends the final $-t$ from the verb est to the first syllable of auri, as well as the synaloepha between the last syllable of uitium and the monosyllable est, which prosodically merges them into a single phonological unit and concretizes the concept of non-dissociation between the idea of "gold" (aurum) and the ones of "lack, crime, guilt" (uitium).

Pent.: the fixed caesura after - $b a t$, added to the spondee of the second foot, hightlights the verb adstabat ("it was built") that ends the first hemistich; this creates a pause for expectation that will be satisfied only when the phrase ante dapes ("before the feast") is reached out at the end of the second hemistich. Thus, there is a transposition here, creating an enhancement in the form of the completive sense of the adverbial phrase ante dapes.

realization everything is a syntagmatic chain, which means that the phoneticphonological reality of the sequence which is called a verse (and of course also that of a sentence) is always a chain of sounds (for example: VÉRTIMVSINSÁ EVASOVÓDDÉDITÍLLEFÉRAS?), in which real breaks may even occur when the rhythm and the semantic content of a sentence require or suggest that, but by no means all the time, what counts in favor of conceiving the caesura, whatever its nature may be, as a more psychological than acoustic phenomenon.

19 On the elegiac topos of refusing war and greed - symbolized here by the reference to gold - as well as the refusal of obtaining wealth in order to praise a life dedicated to the idleness of love, cf. [Boucher $(1965,19-21)$. It is worth noting that some of Ovid's lines describing the Golden Age are also linked to a partly similar reasoning such as: Nondum caesa suis, peregrinum ut uiseret orbem, / montibus in liquidas pinus descenderat undas, / nullaque mortales suas litora norant (Ov. Met. 1.94-6), "No pine had yet, on its high mountain felled, / Descended to the sea to find strange lands / Afar; men knew no shores except their own" Melville $(1986,4)$. In the Golden Age there was no knowledge yet of nautical arts and men therefore did not know other lands, so there was nothing to covet, which also explains there was no need for palisades or ditches to defend the cities (in fact, men had not lived in cities yet) from enemy attacks (Ov. Met. 1.97) and, consequently, the art of war did not even exist (Ov. Met. 1.98-9), 


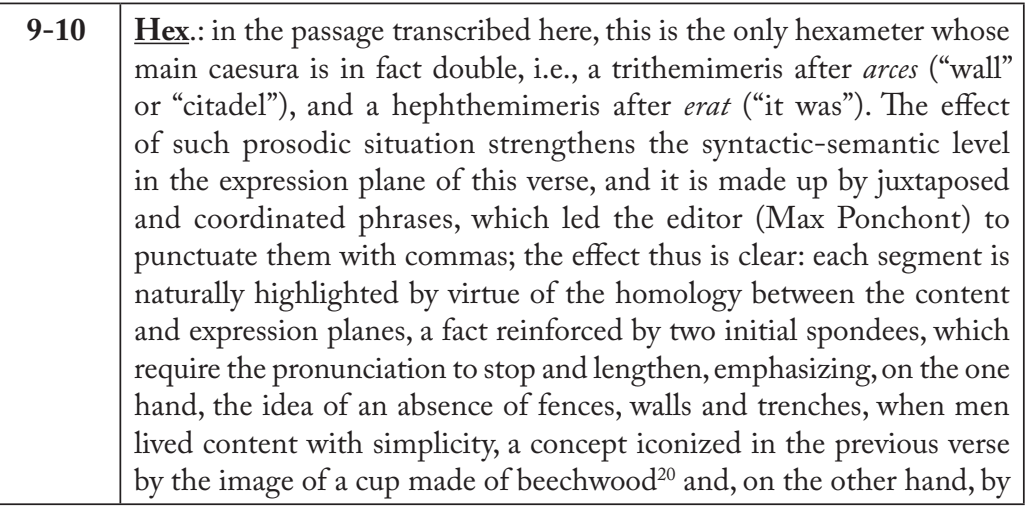

which allowed all people to live safely (Ov. Met. 1.100). The Tibullan elegiac-I rejects the ambition and wars in other passages too, as in the opening verses of Corpus Tibullianum (1.1.1-2), and as Maltby notes, "T.'s rejection of military life is based partly on the implicit moral objection that it is motivated by greed (cf. cupidis). The connection between war and wealth/greed is frequently emphasized by T., e.g. 1.2.67-72, 1.10.7-10, 2.3.41-6; [...]" Maltby $(2002,116)$. It is worth remembering that the criticism of wealth occurs in the context of praising the idealized notion of a farmer living a humble life in the fields: "T. rejects riches in favour of the elegiac ideal of paupertas" Maltby $(2002,117)$; this is a transversal and recurring topos in the elegies of the Corpus Tibullianum, that appears even in the third book whose authorship is uncertain: "More conventional is perhaps his [Lygdamus's] use of the paupertas-theme, 'not wealth, but love', in elegy 3.3. This elegy consists of a series of topoi, such as the uselessness of prayer and the ups and downs of fortune [...], but the dominant topos is the poverty-theme [...]. Although the poem perhaps does not add much to Tibullus 1.1, it shows how the topos might be framed in different ways" Skoie $(2012,92)$. Although the poem does not present any defined time reference, the opening couplet of the elegy I.10 is generally associated with the elegy I.1 and considered as a reference to the Golden Age, because of the absence of wars and swords, of the idealized pastoral life and of rustica paupertas [cf. p. ex., Maltby (2002, 116; 340); Mugatroyd (1980, 280-1). Finally, it is interesting to note the sharp contrast between the criticism of the greed for gold (symbol of wealth) as a peculiar trait of the Iron Age, and the praising of characteristic features of the Golden Age, in which precisely the desire of gold-riches did not exist, a point also highlighted in Ovid's Ars 2.277-8, as pointed out by Maltby (2002, p. 343).

20 It should be noted that the first word in the line 8 is the adjective faginus (beechwood) that contrasts with auri (golden / of gold), which is also the first word in the second hemistich of the line 7; both terms are highlighted (the latter by the caesura, the former by its position in the very head of the line), reinforcing the polarization between the greed of the Iron Age and the rustic simplicity of the Golden Age. The image of the cup made of beechwood has, 
the idea of a shepherd enjoying his calm sleep in the serenity of peaceful surroundings. This idea is conveyed by verses of dactylic and trochaic pacing and it fits well there for being the image of a sweet sleep, as light as one might conceive it; after all, dactyls and trochees are a kind of feet much lighter than spondees. The whole scene will be completed in the next verse by the effect of a slight enjambement.

Pent.: the first hemistich of this verse opens with two long syllables of a spondee, which makes a heavier rhythm (reinforced by the following long syllable - rūs, which belongs to the following metrical foot), alternates to a dactyl that brings a lighter rhythm, and closes with the main caesura after $-\bar{a} s$, which naturally contains another long syllable, after which comes the second and fixed part of the pentameter, beginning by the long syllable of $d u x$ ("leader", "conductor"). Actually, the entire rhythm here graciously alternates along the metrical structure formed by SDlong syllable+DD-long syllable; there are also two secondary caesuras, a trithemimeris after securus ("safe") and another bexamimeris after $d u x$ ("conductor"), which ultimately highlight each of the three initial terms (securus - uarias - dux); once uarias ("spotted") refers to oues ("sheep"), here we have the three most important factors on this bucolic scene: an untroubled herdsman among his ewes; the rhythmic lightness of this verse provides the proper sensation of tranquility of this pastoral scene. Furthermore, the delay in the initial pacing of the pronunciation, obtained by a phonological chain formed by the initial three long syllables, plus the highlighting effect of the caesuras, strengthen the idea of stability and security enjoyed by the conductor of herds ${ }^{21}$, which could then achieve a peaceful sleep in the midst of his mottled ewes grazing scattered, loose and free. Interestingly enough, the word order also composes the image of a safe shepherd among his flock, given that the word dux ("shepherd") is surrounded by uarias ("spotted") and oues ("sheep"). And lastly, the vocalic dispersion caused by a vowel palette that employs almost the entire spectrum of the available Latin vowels ( $\overline{\mathrm{a}}, \breve{\mathrm{e}}$, $\bar{e}, \bar{l}, \bar{i}, \breve{o}, \bar{u})$ also helps to compose the image of a flock of spotted sheep.

indeed, the purpose of functioning as a rustic simplicity icon [cf. Maltby (2002, 344); Murgatroyd (1980, 283)].

21 In the introduction to his comments on the elegy 1.10, Murgatroyd praises the Tibulan image of a lying pastor surrounded by his herd of sheep and feeling safe to get to sleep; the author considers this to be one of the "charming touches" of this elegy [cf. Murgatroyd (1980, 281)]. Commentators usually point out that the adjective uarias acts as an index to the rustica paupertas since mottled wool sheep were less appreciated and less valued than those of a single color [cf. Maltby (2002, 344); Murgatroyd (1980, 284)]. Murgatroyd also indicates two possibilities to interpretate uarias: according to this author, it is either a reference to the mottled color of wool from sheep or it denotes that each one of 


\section{Bibliography}

Cartault, A.1909. Tibulle et les auteurs du Corpus Tibullianum. Texte établi par A. Cartault. Paris: Armand Colin. Félix Alcan.

1911. Le distique élégiaque chez Tibulle, Sulpicia, Lygdamus. Paris:

Dupont, F. 1985. L'Acteur-Roi: le théâtre dans la Rome antique. Paris: Les Belles Lettres.

Fónagy, I. 1966. “Le langage poétique: forme et fonction”. In: Problèmes du langage, Benveniste, Ê. et al., p. 72-116. Paris: Gallimard.

Glare, P. G.W., ed. 1968. Oxford Latin Dictionary (OLD). Oxford (UK): Oxford University Press.

Greimas, A.J., Courtés, A.1983. Dicionário de semiótica. Trad.Alceu Dias Lima et al. São Paulo: Cultrix/EdUSP.

Grimal, P.2005.Dicionário da mitologia grega e romana. 5 a. ed. Trad. Victor Jabouille. Rio de Janeiro: Bertrand Brasil.

Hammond, N.G.L. 2001. Aristotle: Poetics. Transl. by N.G.L.Hammond. Copenhagen (NO): Museum Tusculanum / Univ. of Copenhagen.

Jakobson, R. 1960. "Linguistics and Poetics". In: Style in language, Sebeok, Thomas A., ed. Cambridge (MA-USA): The MIT Press / New-York (USA): John Wiley \& sons.

Juster, A. M. 2012. Tibullus: Elegies. Transl. by A. M. Juster; intro. and notes by Robert Maltby. Oxford (UK): Oxford University Press (Oxford World's Classics).

Maltby, Robert. 2002. Tibullus: elegies. Text, introduction and commentary. Cambridge (UK): Francis Cairns.

Melville, A.D. 1986. Ovid: Metamorphoses. Translated by A.D. Melville, with intro. and notes by E.J. Kenney. Oxford (UK) / New York (USA): Oxford University Press.

them had a different color (ibid.). Whatever the interpretation is, our comment on the figurative relationship between the vowel dispersion presented in this line and the image of sheep variety (be it in different colors for each individual or in multiple colors for every single one) remains true and equally applies. 
Miller, Paul Allen. 2002. Latin erotic elegy. An anthology and reader. Ed. with an introd. and comm. by Paul Allen Miller. London (UK)/New York (USA): Routledge.

Murgatroyd, Paul. 1980. Tibullus I. A commentary on the first book of the elegies of Albius Tibullus. Pietermaritzburg: University of Natal.

Nougaret, L. 1956. Traité de métrique latine classique. 2e. ed. corrigée. Paris: Klincksieck.

Perini, G. B. 1982. "Fondamenti di metrica". In: Propedêutica al latino universitario, Traina, A., Perini, G. B., p. 201-41. 3. ed. Bolonha: Pàtron.

Ponchont, M. 1989. Tibulle et les auteurs du Corpus Tibullianum. 8e. tirage. Paris: Les Belles Lettres.

Postgate,J.P.1912.“Tibullus”. In: Catullus, Tibullus and Pervigium Veneris. Translated respect. by F. W. Cornish, J. P. Postgate and J. W. Mackail, p. 185-339. London (UK): William Heinemann / New York (USA): Macmillan Co. (Loeb).

Rosset, C. 1970. L'Enseignement élémentaire du Latin. Paris: Université de Paris IV-Sorbonne.

Skoie, Mathilda. 2012. "Corpus Tibullianum, Book 3". In: A companion to Roman love elegy, GOLD, Barbara K., p. 86-100. Malden (MA-USA)/ Oxford (UK): Wiley-Blackwell.

Vernant,Jean-Pierre. 1965. "Genèse et structure dans le mythe hésiodique des races". In: Entretiens sue les notions de Génèse et de Strutucture, Gandillac, Maurice de, Goldmann, Lucien, Piaget, Jean (ed.), p. 95-124. Centre Culturel International de Cerisy-La-Salle: Mouton \& Co.

Whiton, James Morris. 1879. Auxilia Vergiliana. First steps in Latin prosody. Boston: Ginn\&Heath.wool from sheep or it denotes that each one of them had a different color (ibid.). Whatever the interpretation is, our comment on the figurative relationship between the vowel dispersion presented in this line and the image of sheep variety (be it in different colors for each individual or in multiple colors for every single one) remains true and equally applies. 